\title{
Dermatologic aspects of bed bug epidemic: an atlas of differential diagnosis
}

\author{
Luca Fésüs ${ }^{1}$, Antal Jobbágy ${ }^{1}$, Norbert Kiss ${ }^{1}$, Eszter Horváth ${ }^{1}$, Pinar Avci' ${ }^{1}$, Andrea Lukács ${ }^{1}, K^{2}$ atalin Mayer ${ }^{2}$, \\ Beata Bergler-Czop ${ }^{3}$, Norbert Wikonkál' ${ }^{1}$, András Bánvölgyi ${ }^{1}$
}

${ }^{1}$ Department of Dermatology, Venerology and Dermatooncology, Semmelweis University, Budapest, Hungary ${ }^{2}$ Hospital for Small Animals Dunakeszi, Dunakeszi, Hungary

${ }^{3}$ Department of Dermatology, School of Medicine, Medical University of Silesia, Katowice, Poland

Adv Dermatol Allergol 2021; XXXVIII (2): 184-192 DOI: https://doi.org/10.5114/ada.2021.106194

\begin{abstract}
Bed bug infestation rate has gone through an unforeseen increase in the past decades worldwide. Their resurgence is a consequence of numerous factors, including growing population density, increased international travel and the spread of insecticide resistance. Bed bug infestation is often revealed by skin symptoms appearing after their bite in sensitive patients. Medical professionals encountering patients with bed bug bites have responsibility for recognizing the condition and for instructing patients about the necessary measures for eradication. Setting the correct diagnosis, however, is not unequivocal as several skin diseases with autoimmune, immune-mediated aetiology or other arthropod stings and bites may present with similar symptoms. In this review we provide a differential diagnostic guide and an atlas of clinical pictures assigned to the diagnoses. We highlight those dermatological findings where the possibility of bed bug bite arises and identify key elements that help in the differentiation so as to avoid unnecessary diagnostic tests and force early start of extermination.
\end{abstract}

Key words: bed bug, Cimex lectularius, differential diagnosis, infestation, arthropod bite.

\section{Introduction}

Patients usually visit their general practitioner's office first when they experience a sudden appearance of maculopapular skin lesions. These cases are often referred to dermatologists, where bed bug bite is among the possibly established diagnoses. Recently, an emerging number of bed bug infestations and difficulties with their eradication have been reported [1, 2]. The broad range of possible differential diagnostic options and the frustration of patients affected prompted us to summarize our own experiences and review the literature with special attention to differential diagnosis.

Bed bugs are 5-8 $\mathrm{mm}$ reddish-brown arthropods, visible to the naked eye $[3,4]$. They tend to avoid light and hide in warm and dark places such as mattresses, box springs, carpets, behind headboards, wallpapers and little cracks in walls. Indirect visible signs such as cast skin, faecal specks and blood spots on bedclothes may prove helpful in their detection $[5,6]$. Bed bugs only forage during the night and it is the easiest to find them during their peak mealtime around 3 am. Exposed skin such as the face, neck, and extremities are the most common sites for bites. Characteristically, three distinct small round bite marks located a few centimetres apart and arranged in a linear or triangular fashion can be observed. This pattern is referred to as "breakfast, lunch, and dinner" sign [7]. Mature bed bugs can stay alive for 12 months without feeding. Such resilience can, in part, explain their widespread incidence around the world [6].

\section{Epidemiology}

Contrary to common belief, the battle of coexistence between humans and beg bugs has been ongoing for centuries. From the ancient Greek scripts of Aristophanes, the Latin Horace to the Jewish Talmud, this opportunist appears in various texts [8]. Even the term "bed bug" (Cimex lectularius) originates from the ancient Rome. In Latin, cimex means insect, while lectularius refers to a bed [6]. Moreover, surveys from the

Address for correspondence: András Bánvölgyi, Department of Dermatology, Venerology and Dermatooncology, Semmelweis University, 41 Mária St, 1085 Budapest, Hungary, phone: +36 306663533, e-mail: banvolgyi.andras@gmail.com, bettina2@tlen.pl Received: 8.11.2019, accepted: 24.03.2020 
early $20^{\text {th }}$ century revealed that bed bugs had infested approximately $30 \%$ of the apartments in the major cities of the United States [9]. Urban prevalence in Europe was also peaking in the 1930s, affecting about one-third of the living quarters [10]. It was not until World War II that the investments on research and development of effective pesticides reduced this number near to zero [11, 12]. However, to everyone's surprise, by the turn of the millennium, bed bugs started to re-invade homes of many residents, and this insidious resurge caught the attention of public and health authorities at a much later time than one would anticipate $[1,2,5,13]$. Moreover, current bedbug epidemic is a serious healthcare problem not just in the developing countries but also in North America [11, 14], Europe [1], and Australia [15]. For instance, only in Australia, a 4,500\% increase in infestations was observed between 2000 and 2006 [16].

Presumable causes for this significant rise in the incidence are the substantial increase in international travel, intercontinental migration, changes in pesticide control management, and development of pesticide resistance [17-21]. Among other predisposing risk factors, we should highlight urbanization, congested cities and low-income housing communities as the most common ones [22]. Person-to-person transmission is rare, but bed bugs can migrate through water pipes, walls and infest the neighbouring building or apartment [17]. Despite the lack of registries, England was one of the first countries to raise the concern of a possible bed bug epidemic outbreak with a letter addressed to the editor of the British Medical Journal in 2000 [2]. In France, a new initiative was started in 2009 to inform and educate the public and health care professionals about the identification of bed bug infestations, how to recognize bites and also to develop effective monitoring and control strategies [1]. Around the same time, a bed bug summit was held in the United States [23], where the current infestation rate is about $10 \%$ [24].

Raising awareness of family doctors, dermatologists, emergency workers, paediatricians and nurses who are at the forefront in the diagnosis is of uppermost importance. Their role is also critical not only in reducing unwarranted social stigma but also in guiding the patient regarding the eradication process and the avoidance of reinfection.

\section{Clinical findings}

The bite itself is painless, the wheal that the bite induces lasts only for 3-15 min. Besides the irritating-toxic reaction, immune-mediated symptoms may appear in most people provoked by the proteins in the saliva of bed bugs $[25,26]$. The various clinical presentation is greatly depending on the affected individuals and previous exposures [17, 27]. Bed bug bite-naive patients usually show no skin reaction after the first exposure, thus the infestation may remain undetected. A re-infestation leads to skin symptoms appear after 6-11 days in sensitized patients. Additional encounters provoke symptoms that appear with a decreased latency of 2-3 days, then only hours, thus making skin signs being noticed in the next morning [28]. The incidence of immune-mediated hypersensitivity is variable, asymptomatic infestation insensitivity - is estimated to range at 4.2-25\% [28]. According to a survey among infested dwelling inhabitants in the USA, more females react to bites than males, and an elderly age is a protective factor as significantly more individuals showed no allergic bite reaction in those over the age of 65, compared to people aged 11 to 65 (42\% vs. $26 \%$ ). Mosquito bite sensitivity also correlated with reactivity to bed bug bites [29].

There have been several attempts to categorize bed bug bite reactions, which can be either cutaneous or systemic reactions. Cutaneous symptoms may be - according to their frequency - usual, common and complex. A usual symptom refers to a small punctum without any reaction, whereas common symptoms are $2-5 \mathrm{~mm}$ pruritic, maculopapular lesions [17]. These lesions do not fade upon pressure, the central puncture mark - that can be haemorrhagic - is surrounded by an erythematous border. The rash is not confluent, nor are there areas of weeping or sloughing $[5,6,30]$. Complex symptoms are wheals, papular urticaria and blisters that long extend the bite mark [17, 19, 31-36]. Papular urticaria is considered to be a hypersensitivity reaction characteristic in atopic children, provoked by immunoglobulin (Ig) $G$ antibodies, usually disappearing within hours, but sometimes also persisting for days [5, 6, 37]. A few case reports have described bullous, type 3 hypersensitivity to a bed bug bite [25, 27, 28], however, another study claims that it is found in $6 \%$ of the patients [34]. These reactions are extremely pruritic, may be haemorrhagic and may be associated with lymphangitis $[19,38]$. Some of these reactions are delayed up to a week or even more [39]. Moreover, it is not uncommon that superinfections develop, especially in case of intense pruritus.

There are only singular cases on systemic reactions such as asthma, angioedema and hypertension, generalized urticaria and anaphylaxis [17, 38]. These can appear without the development of previous skin symptoms, as presented by one report [40].

\section{Diagnosis}

Diagnosis is made upon physical examination and history of possible exposure. Blood drops, faecal smears on bed linen, under the mattresses or noticing the bug itself can confirm the suspicion. Clinical appearance with the often linear orientation and medical history are usually enough to make a proper diagnosis [19]. Anamnestic data like living in a workers' hostel, nursing home or shelters, being on a vacation, buying new or used wooden made furniture 
raises the attention to possible bed bug bite. Affected family members also confirm the suspicion, however, according to our observation, negative family anamnesis is quite usual, as bed bugs often attack only one person.

In some compound cases, additional examinations are necessary to figure out the diagnosis. Immunological tests can prove to be helpful in the diagnosis of certain ambiguous cases. Prick testing with the bed bugs' salivary gland solution is an effective, rapid and safe method to demonstrate both immediate and late-phase reactions, but is generally not available [40]. Serum specific IgE antibody levels against nitrophorin can also be elevated. Serological analysis, however, does not necessarily reveal systemic infection or the presence of specific IgG autoantibodies in bullous cases [25]. There is no specific sign of the bed bug bites on a histology section, although it can come handy in excluding other diseases [27].

\section{Differential diagnosis}

As the clinical manifestation of bed bug bites shows a wide variety, these reactions often lead to diagnostic confusion [34]. We sought out to organize occurring dermatologic diseases that may resemble bed bug bites and to give substantive and dense information on possible similarities and differences for guidance in recognition of the underlying condition. We do not tempt to give a full diagnostic algorithm for the highlighted diseases as this would go beyond the scope of this article and we propose orientating clinicians between the skin conditions with distinct aetiology. Other arthropod stings or bites certainly arise as differential options (Table 1). Moreover, ectoparasitic arthropod infestations also have to be incurred (Table 1). Furthermore, immune-mediated and autoimmune diseases comprise a large group of dermatologic conditions that could manifest with similar symptoms (Table 2). Last, but not least, infections and psychodermatological diseases may also mimic bed bug bites (Table 1). We summarize how they share similarities and what the significant differences are in Tables 1 and 2, supplemented with clinical image pairs (Figures 1 and 2), where we show the wide variation of bed bug bites and how these with the aforementioned skin conditions can mimic each other. Clinical photographs were captured

Table 1. Similarities and differences in the clinical appearance of stinging and biting arthropods, ectoparasites or other dermatological diseases and bed bug bites

\begin{tabular}{|c|c|c|}
\hline Diagnosis & Similarities & Differences \\
\hline \multicolumn{3}{|l|}{ Stinging and biting arthropods: } \\
\hline Honeybee, wasp sting [49] & $\begin{array}{l}\text { Painful and/or pruritic wheal, flare with } \\
\text { a central punctum }\end{array}$ & $\begin{array}{l}\text { Single lesion. Immediate reaction, systemic reactions are } \\
\text { not rare. Patients are aware of the bite }\end{array}$ \\
\hline Spider bite [50] & $\begin{array}{l}\text { Painful and/or pruritic wheal, flare or } \\
\text { papule with a central punctum }\end{array}$ & $\begin{array}{l}\text { Single or few lesions with 1-2 new lesions per day. } \\
\text { Diameter is between } 1-40 \mathrm{~cm}\end{array}$ \\
\hline \multicolumn{3}{|l|}{ Ectoparasites: } \\
\hline Tick [51] & $\begin{array}{l}\text { Erythematous papule with a central } \\
\text { punctum }\end{array}$ & $\begin{array}{l}\text { Single lesion without itch. Report about being in the nature. } \\
\text { Ticks may remain attached to the skin for a longer time }\end{array}$ \\
\hline Body lice [52] & $\begin{array}{l}\text { Multiple erythematous papules, } \\
\text { excoriation }\end{array}$ & $\begin{array}{l}\text { Symptoms under clothing. Diameter of the lesions is } \\
3-5 \mathrm{~mm} \text {. Lice and their eggs are visible }\end{array}$ \\
\hline Flea [52] & $\begin{array}{l}\text { Multiple bites on the extremities and } \\
\text { trunk. Can occur in a linear pattern }\end{array}$ & $\begin{array}{l}\text { Presence of animals. Diameter of the lesion is maximum } \\
5-10 \mathrm{~mm}\end{array}$ \\
\hline Scabies [53] & $\begin{array}{l}\text { Pruritic erythematous papules in } \\
\text { predilection sites - interdigital, sacral, } \\
\text { genital area, wrists }\end{array}$ & $\begin{array}{l}\text { Diameter of the lesion is } 3-5 \mathrm{~mm} \text {. Symptoms appear after } \\
3-6 \text { weeks. Itch during night. Different predilection areas }\end{array}$ \\
\hline \multicolumn{3}{|l|}{ Other diseases: } \\
\hline Bullous erysipelas [54] & $\begin{array}{l}\text { Bullae with serous or haemorrhagic } \\
\text { fluid. Unilateral distribution is possible. } \\
\text { Limbs affected }\end{array}$ & $\begin{array}{l}\text { Only one limb, always unilateral. Fever is present. Extensive } \\
\text { erythema, flame-pattern. Confluent bullae }\end{array}$ \\
\hline $\begin{array}{l}\text { Delusions of parasitosis } \\
\text { (Ekbom syndrome) [55] }\end{array}$ & $\begin{array}{l}\text { Erythematous papules. Severe pruritus, } \\
\text { excoriations }\end{array}$ & $\begin{array}{l}\text { Centre of the back and face is spared. Psychiatric } \\
\text { anamnesis. Feel of constant biting, crawling. Patients tend } \\
\text { to "remove the pathogens" and are convinced about having } \\
\text { an infestation }\end{array}$ \\
\hline Herpes zoster [56] & $\begin{array}{l}\text { Painful vesicles with erythematous } \\
\text { base, rarely linear arrangement }\end{array}$ & $\begin{array}{l}\text { Unilateral grouped vesicles following a dermatome, except } \\
\text { for the disseminated form }\end{array}$ \\
\hline $\begin{array}{l}\text { Reactive perforating } \\
\text { collagenosis [57] }\end{array}$ & $\begin{array}{l}\text { Erythematous papule with central } \\
\text { erosion, usually pruritic. Appears on } \\
\text { limbs }\end{array}$ & $\begin{array}{l}\text { Acquired form with diabetes or chronic renal failure. } \\
\text { Lesions may be a response to superficial trauma, scratching }\end{array}$ \\
\hline
\end{tabular}


Table 2. Similarities and differences in the clinical appearance of autoimmune or immune-mediated dermatological diseases and bed bug bites

\begin{tabular}{|c|c|c|}
\hline Diagnosis & Similarities & Differences \\
\hline \multicolumn{3}{|c|}{ Autoimmune/immune-mediated diseases: } \\
\hline $\begin{array}{l}\text { Allergic contact } \\
\text { dermatitis [58] }\end{array}$ & $\begin{array}{l}\text { Papules, vesicles or bullae, with erythematous } \\
\text { base and distinct border. Severe itching }\end{array}$ & $\begin{array}{l}\text { Vesicles tend to coalesce. Patients may report the } \\
\text { causative agent }\end{array}$ \\
\hline Bullous pemphigoid [5] & $\begin{array}{l}\text { Tense bullae with erythematous base, severe itching. } \\
\text { Limbs and the trunk region are mostly affected }\end{array}$ & $\begin{array}{l}\text { Elderly people are affected. Symmetrical. Affects } \\
\text { flexural areas of the limbs and also mucosa }\end{array}$ \\
\hline $\begin{array}{l}\text { Dermatitis } \\
\text { herpetiformis [59] }\end{array}$ & $\begin{array}{l}\text { Papules, vesicles on the extensor surfaces of the } \\
\text { thighs, elbows, buttocks. Extensive itching }\end{array}$ & $\begin{array}{l}\text { Symmetrical appearance, long-term history. } \\
\text { Associated with intestinal symptoms in } 20 \%\end{array}$ \\
\hline $\begin{array}{l}\text { Erythema multiforme } \\
\text { [60] }\end{array}$ & $\begin{array}{l}\text { Erythematous-blanche "targetoid" lesions on } \\
\text { elbows, palms and knees. Blisters can occur }\end{array}$ & $\begin{array}{l}\text { Symmetrical. Pain and mucosal involvement can } \\
\text { occur. HSV infection or drug intake often precede } \\
\text { symptoms }\end{array}$ \\
\hline $\begin{array}{l}\text { Linear IgA dermatosis } \\
\text { [61] }\end{array}$ & Tense vesicles and bullae, erythematous base & $\begin{array}{l}\text { Annular distribution. Mucous membrane } \\
\text { involvement can occur }\end{array}$ \\
\hline $\begin{array}{l}\text { Lymphomatoid } \\
\text { papulosis [62] }\end{array}$ & $\begin{array}{l}\text { Erythematous/red-brown papulonodules. Central } \\
\text { ulcerations can occur. Limbs and trunk region }\end{array}$ & $\begin{array}{l}\text { Single or few lesions. Chronic recurrent. Often } \\
\text { leaves residual scarring }\end{array}$ \\
\hline $\begin{array}{l}\text { Papulovesicular } \\
\text { polymorphous light } \\
\text { eruption [63] }\end{array}$ & Erythematous blisters, papules. Itching can occur & $\begin{array}{l}\text { Monomorphic lesions in a given patient. Eruptions } \\
\text { after sunlight-exposure, on sun-exposed areas }\end{array}$ \\
\hline $\begin{array}{l}\text { Phytophotodermatitis } \\
\text { [64] }\end{array}$ & $\begin{array}{l}\text { Blisters, plaques in a linear distribution affecting } \\
\text { the distal part of extremities }\end{array}$ & $\begin{array}{l}\text { After outdoor activity. Continuous lines, not solitary } \\
\text { papules in linear pattern }\end{array}$ \\
\hline $\begin{array}{l}\text { Pityriasis lichenoides } \\
\text { chronica [65] }\end{array}$ & $\begin{array}{l}\text { Erythematous papules, nodules. Limbs and trunks } \\
\text { are commonly affected sites }\end{array}$ & $\begin{array}{l}\text { Prominent scaling, shiny surface. Lesions are at } \\
\text { different stages of development. Long-term history }\end{array}$ \\
\hline $\begin{array}{l}\text { Pityriasis lichenoides et } \\
\text { varioliformis acuta [66] }\end{array}$ & $\begin{array}{l}\text { Erythematous papules, vesicles. May be pruritic. } \\
\text { Central haemorrhage mimics the punctum. The } \\
\text { trunk and limbs are mostly affected }\end{array}$ & $\begin{array}{l}\text { Scaling, lesions at different stages. Affects flexural } \\
\text { sites of extremities. Linear pattern is missing }\end{array}$ \\
\hline Prurigo nodularis [67] & $\begin{array}{l}\text { Excoriated erythematous papules, nodules, severe } \\
\text { itching. Affects extensor surface of limbs }\end{array}$ & $\begin{array}{l}\text { Symmetrical. The central back is spared. Long-term } \\
\text { history, slow development }\end{array}$ \\
\hline $\begin{array}{l}\text { Pruritic urticarial } \\
\text { papules and plaques } \\
\text { of pregnancy [68] }\end{array}$ & $\begin{array}{l}\text { Pruritic, erythematous wheals, papules, plaques, } \\
\text { seropapules. Linear arrangement }\end{array}$ & $\begin{array}{l}\text { Linearity follows striae with periumbilical sparing. } \\
\text { Proximal region of the limbs is affected. Onset in } \\
\text { the third trimester of pregnancy }\end{array}$ \\
\hline Sweet-syndrome [69] & $\begin{array}{l}\text { Erythematous to purple, tender papules, plaques, } \\
\text { blisters. Limbs, neck and upper back region }\end{array}$ & $\begin{array}{l}\text { Fever, neutrophilia is present. May involve mucosa } \\
\text { and other organs. Onset after infection, drug intake } \\
\text { or chronic illness }\end{array}$ \\
\hline Toxicoderma [70] & Wheals, maculopapules, blisters. Itching can occur & $\begin{array}{l}\text { Drug intake in history, time lapse from drug intake } \\
\text { is } 1-21 \text { days. Lesions tend to coalesce, head-to-toe } \\
\text { change in distribution }\end{array}$ \\
\hline Urticaria [71] & Multiple hives, intensely itching & $\begin{array}{l}\text { Vary in size and shape. Changing location in } \\
\text { maximum } 48 \text { h. Appear anywhere on the body }\end{array}$ \\
\hline Urticaria vasculitis [71] & $\begin{array}{l}\text { Erythematous hives, central palpable purpura. } \\
\text { Lesions last over } 48 \mathrm{~h}\end{array}$ & $\begin{array}{l}\text { Vary in size and shape. Residual central } \\
\text { hyperpigmentation. Pattern is not linear }\end{array}$ \\
\hline
\end{tabular}

by the authors or selected from the clinical photography database of our department following patient's consent.

\section{Treatment and eradication}

Most skin signs spontaneously regress within 310 days [19]. Only symptomatic treatment is available without standard guidelines. The pruritus may be alleviated with over-the-counter topical products (pramoxine, doxepin) or systemic antihistamine (desloratadine, bilastine) treatment. Topical corticosteroids (triamcino- lone, mometasone) are a good combination with the previous ones due to dual effect. Superinfection should be treated with topical mupirocin or systemic antibiotics and systemic reactions should be managed according to the symptoms. Individuals with extensive and/or bullous reactions may require oral corticosteroids [17, 27].

The crucial and yet most challenging step is the eradication of bed bugs from the host environment. Nowadays, commercially available products and specialised companies are engaged in eradication. Integrated pest management is the most effective approach in multi-dwelling settings to 

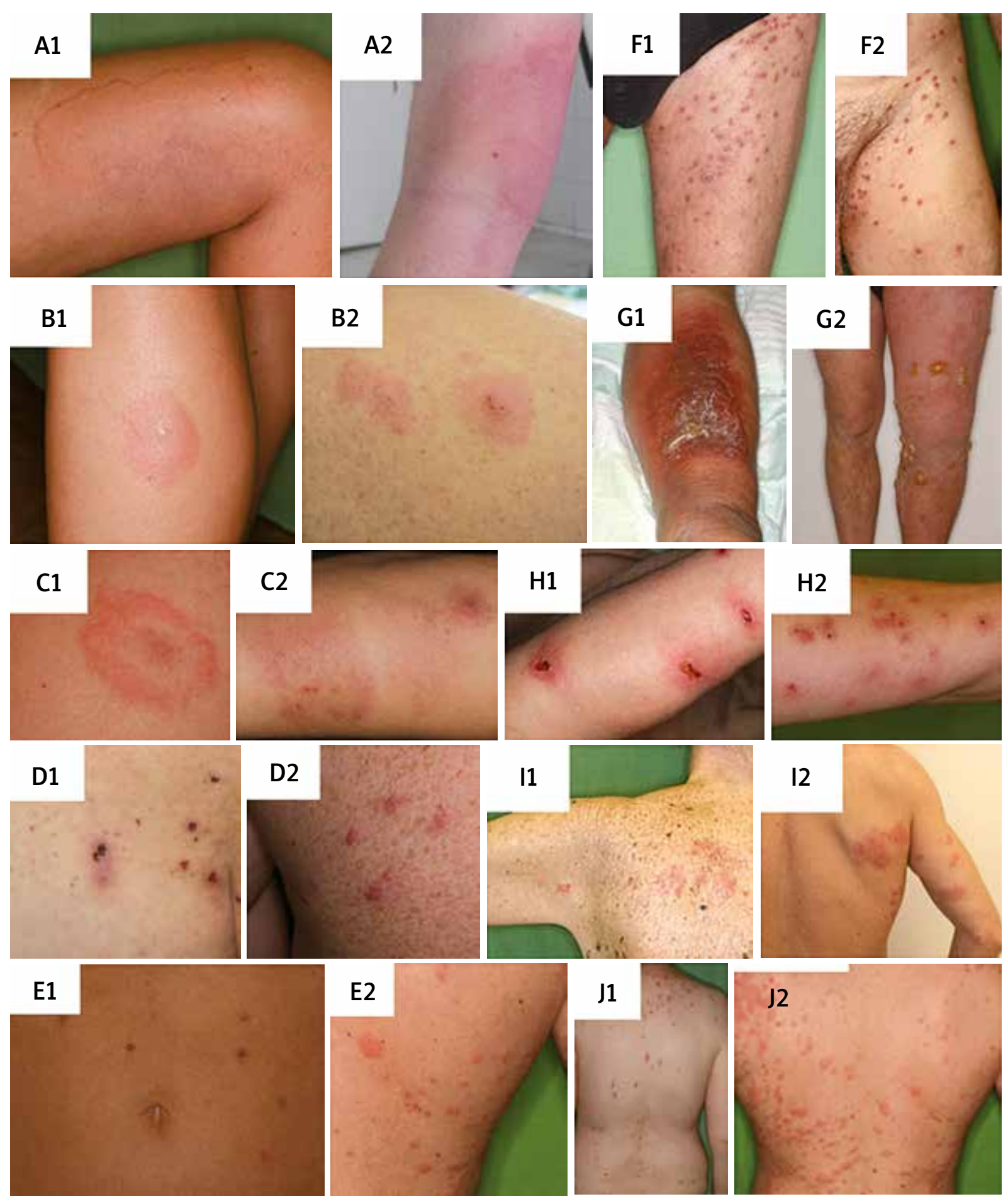

Figure 1. Clinical images corresponding to Table 1. A1 - Honeybee sting. B1 - Spider bite. C1 - Tick. D1 - Body lice. E1 - Flea. F1 - Scabies. G1 - Bullous Erysipelas. H1 - Delusions of parasitosis (Ekbom syndrome). I1 - Herpes zooster. J1 - Reactive perforating collagenosis. A2-J2 - Bed bug bite reactions.

eliminate bed bugs [41]. Until this is reached, it is advisable to repel them with $5 \%$ permethrin cream or $40 \%$ diethyltoluamide (DEET) applied to the skin [42]. In 2016, an American eradication protocol was also established to provide stepwise guide [22]. Other European, American and Austra- lian guidelines are also available addressing both military, industrial and healthcare professionals [29, 43-45].

If the infestation is not extensive, a physical method solely can be a proper choice. As a room treatment, vacuuming, steam, dry ice or heat treatment are the 


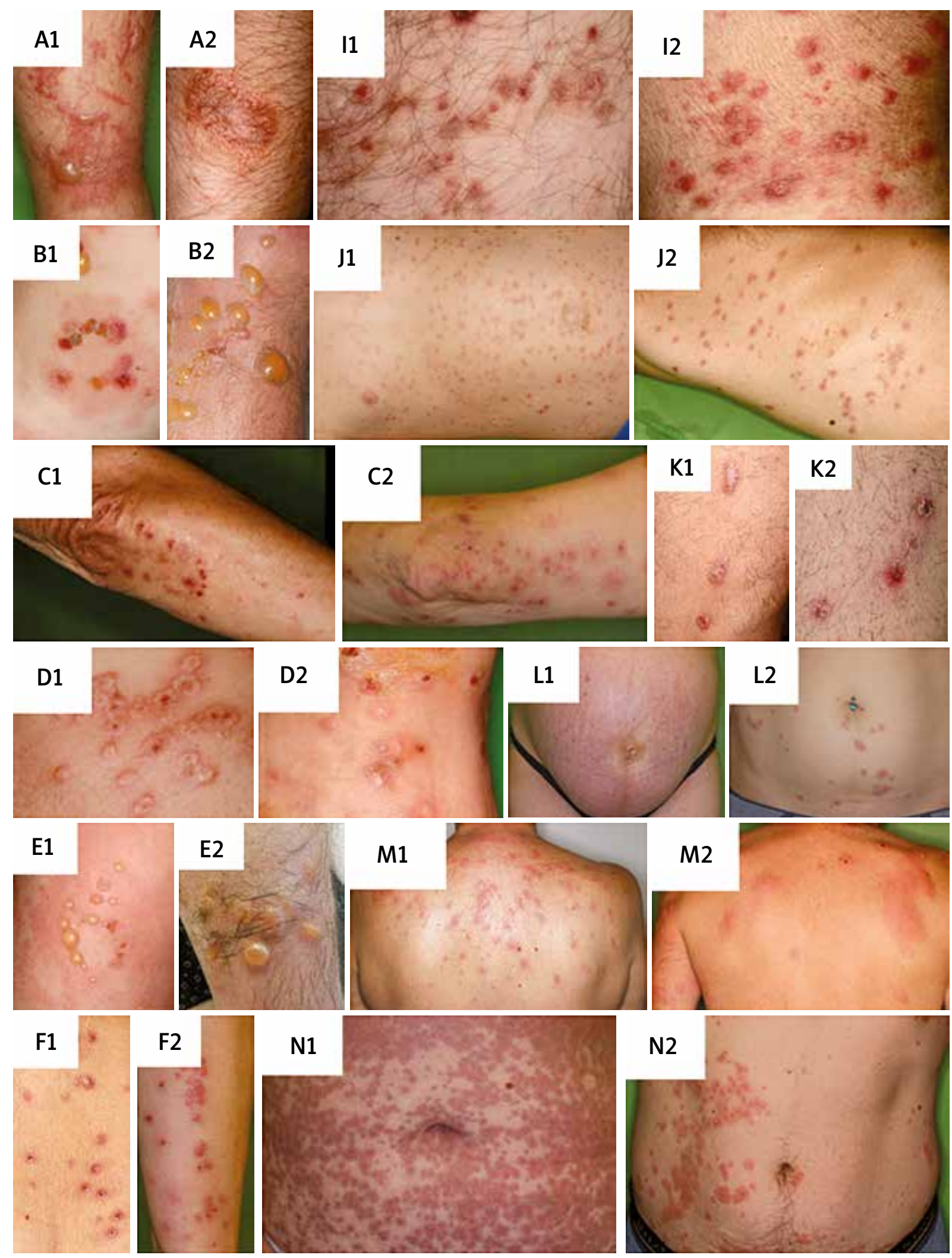

Figure 2. Clinical images corresponding to Table 2. A1 - Allergic contact dermatitis. B1 - Bullous pemphigoid. C1 - Dermatitis herpetiformis. D1 - Erythema multiforme. E1 - Linear IgA Dermatosis. F1 - Lymphomatoid papulosis. G1 - Papulovesicular polymorphous light eruption. H1 - Phytophotodermatitis. I1 - Pityriasis lichenoides chronica. J1 - Pityriasis lichenoides et varioliformis acuta. K1 - Prurigo nodularis. L1 - Pruritic urticarial papules and plaques of pregnancy. M1 - Sweet-syndrome. N1 - Toxicoderma. 01 - Urticaria. P1 - Urticaria vasculitis. A2-P2 - Bed bug bite reactions 


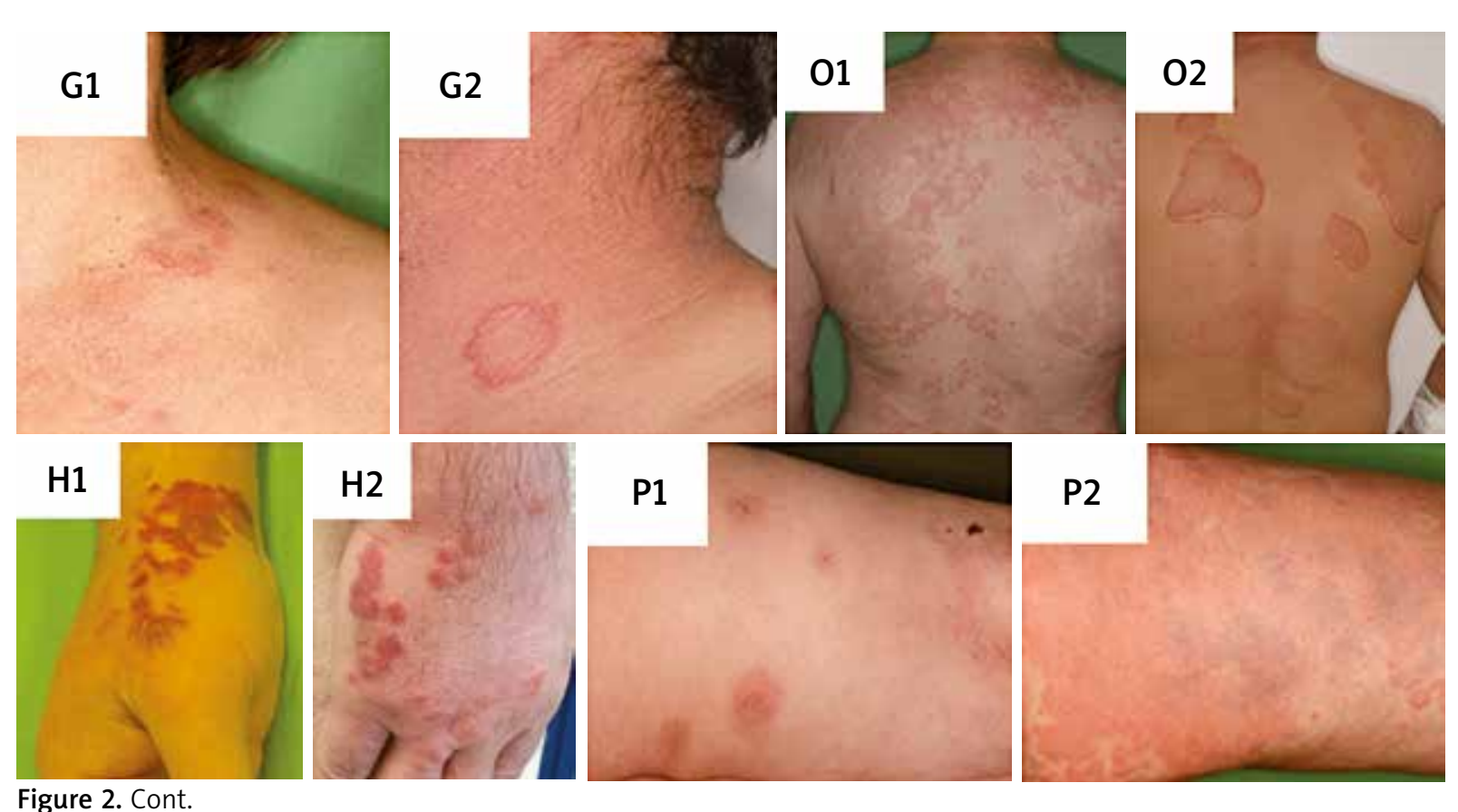

options to be followed, while movable item disinfestation should be made by laundry, tumble drying, portable heating units, freezing or with oxygen removal. To control extensive or well-established bed bug infestation, the application of chemical methods is necessary [19], although emerging resistance makes professional pest control companies use pesticides as pyrethroids and carbamates in synergist combination and in different formulations for effective extermination [18, 19].

Avoiding exposure as prevention remains thus the best treatment. If buying furniture or travelling, check for signs of infestation. Move the bed away from the walls and keep blankets from touching the floor. In the case of an infested area, inspect the luggage before departure [19].

\section{Discussion}

The cost of eradication, the absence from work in severe cases raises the question with public health significance. Mental health impact of bed bugs is also discussed in the literature, these consequences can be serious, but their relation is poorly understood. A case report presents suicide upon uncontrolled infestation. Even though the subject there had an underlying psychiatric illness, unsuccessful eradication with triggering phobia and amplifying mental symptoms ultimately led to life determination [46]. Susser et al. assessed anxiety and sleep disturbance in bed bug exposed tenants, compared to controls and found a significant association of these symptoms measured with validated criteria with exposure [47]. A survey conducted in dwellings with confirmed infestation reported sleep disturbance, insomnia, nervousness and distress in $20-29 \%$ of people affected [29]. According to a literature review, more than half of the articles mention psychological associations. Most of the articles claim that chronic infestation could provoke anxiety, phobia, PTSD, depression and psychosis [48]. Chronic infestation was also claimed to have consequences as diarrhoea and iron deficiency anaemia [6]. Social stigma and socio-occupational dysfunction has an inherent adverse impact on patients' lives, as many consider infestation as a consequence of poor hygiene, which together with the prominent symptoms lead to isolation and absence from work. The high cost of extermination, replacement of furnishing articles and re-clothing further aggravate its economic impact [48]. Eradication is indeed expensive, in the USA it amounts from USD 800 to USD 1,200 for one single dwelling [18]. There are no statistical data so far on the cost of unnecessary medical diagnostic tests that are requested before the proper diagnosis is established, but this must also be significant. We here aimed to give a synopsis of bed bug bites from the clinician's view with a particular emphasis on potential differential diagnostic options to raise awareness to bed bug infestation and provide assistance for medical practitioners to facilitate early diagnosis and treatment.

\section{Acknowledgments}

Norbert Wikonkál and András Bánvölgyi share senior authorship.

The work should be attributed to the Department of Dermatology, Venerology and Dermatooncology, Semmelweis University, Hungary, Mária street 41, 1085 Budapest. Head of the Institution: Prof. Miklós Sárdy, MD PhD. 
We are grateful to Rita Mátrahegyi, clinical photographer of our department for capturing clinical images for this article.

\section{Conflict of interest}

The authors declare no conflict of interest.

\section{References}

1. Levy Bencheton A, Berenger JM, Del Giudice P, et al. Resurgence of bedbugs in southern France: a local problem or the tip of the iceberg? J Eur Acad Dermatol Venereol 2011; 25: 599-602.

2. Paul J, Bates J. Is infestation with the common bedbug increasing? BMJ 2000; 320: 1141

3. Francischetti IM, Calvo E, Andersen JF, et al. Insight into the Sialome of the Bed Bug, Cimex lectularius. J Proteome Res 2010; 9: 3820-31.

4. Valenzuela JG, Walker FA, Ribeiro JM. A salivary nitrophorin (nitric-oxide-carrying hemoprotein) in the bedbug Cimex lectularius. J Exp Biol 1995; 198: 1519-26.

5. Shmidt E, Levitt J. Dermatologic infestations. Int J Dermatol 2012; 51: 131-41.

6. McMenaman KS, Gausche-Hill M. Cimex lectularius ("Bed Bugs"): recognition, management, and eradication. Pediatr Emerg Care 2016; 32: 801-6.

7. Peres G, Yugar LBT, Haddad Jr V. Breakfast, lunch, and dinner sign: a hallmark of flea and bedbug bites. An Bras Dermatol 2018; 93: 759-60.

8. Davies TG, Field LM, Williamson MS. The re-emergence of the bed bug as a nuisance pest: implications of resistance to the pyrethroid insecticides. Med Vet Entomol 2012; 26: 241-54.

9. Gangloff-Kaufmann JL, Pichler C. Guidelines for prevention and management of bed bugs in shelter and group living facilities. Cornell University 2008.

10. Potter MF. The history of bed bug management - with lessons from the past. Am Entomol 2011; 57: 14-25.

11. Anderson AL, Leffler K. Bedbug infestations in the news: a picture of an emerging public health problem in the United States. J Environ Health 2008; 70: 24-7, 52-3.

12. Sfeir M, Munoz-Price LS. Scabies and bedbugs in hospital outbreaks. Curr Infect Dis Rep 2014; 16: 412.

13. Lee IY, Ree HI, An SJ, et al. Reemergence of the bedbug Cimex lectularius in Seoul, Korea. Korean J Parasitol 2008; 46: 269-71.

14. Hwang SW, Svoboda TJ, De Jong IJ, et al. Bed bug infestations in an urban environment. Emerg Infect Dis 2005; 11: 533-8.

15. Doggett SL, Orton CJ, Lilly DG, et al. Bed bugs: the Australian response. Insects 2011; 2: 96-111.

16. Doggett SL, Russell R. Bed bugs - what the GP needs to know. Aust Fam Physician 2009; 38: 880-4.

17. Goddard J, deShazo R. Bed bugs (Cimex lectularius) and clinical consequences of their bites. JAMA 2009; 301: 1358-66.

18. Doggett SL, Dwyer DE, Penas PF, et al. Bed bugs: clinical relevance and control options. Clin Microbiol Rev 2012; 25: 164-92.

19. Cleary CJ, Buchanan D. Diagnosis and management of bedbugs: an emerging U.S. Infestation. Nurse Pract 2004; 29: 46-8.
20. Romero A, Potter MF, Haynes KF. Evaluation of piperonyl butoxide as a deltamethrin synergist for pyrethroid-resistant bed bugs. J Econom Entomol 2009; 102: 2310-5.

21. Potter MF. The perfect storm: an extension view on bed bugs. Am Entomol 2006; 52: 102-4.

22. Cooper RA, Wang C, Singh N. Evaluation of a model community-wide bed bug management program in affordable housing. Pest Manag Sci 2016; 72: 45-56.

23. Anderson A. The decade of bedbugs and fear. Environ Health Insights 2011; 5: 53-4.

24. Wu Y, Tracy DM, Barbarin AM, et al. A door-to-door survey of bed bug (Cimex lectularius) infestations in row homes in Philadelphia, Pennsylvania. Am J Trop Med Hyg 2014; 91: 206-10.

25. Leverkus M, Jochim RC, Schad S, et al. Bullous allergic hypersensitivity to bed bug bites mediated by lgE against salivary nitrophorin. J Invest Dermatol 2006; 126: 91-6.

26. Fujishita M, Kataoka R, Kobayashi M, et al. Williams-Campbell syndrome complicated by multiple meniscus signs in an adult case; is it a characteristic finding?. Nihon Kyobu Shikkan Gakkai Zasshi 1990; 28: 1018-23.

27. deShazo RD, Feldlaufer MF, Mihm MC Jr, et al. Bullous reactions to bedbug bites reflect cutaneous vasculitis. Am J Med 2012; 125: 688-94.

28. Reinhardt K, Kempke D, Naylor RA, et al. Sensitivity to bites by the bedbug, Cimex lectularius. Med Vet Entomol 2009; 23: 163-6.

29. Potter MF, Haynes KF, Connelly K, et al. The sensitivity spectrum: human reactions to bed bug bites. Pest Control Technology 2010; 38: 70-4.

30. Ter Poorten MC, Prose NS. The return of the common bedbug. Pediatr Dermatol 2005; 22: 183-7.

31. Scarupa MD, Economides A. Bedbug bites masquerading as urticaria. J Allergy Clin Immunol 2006; 117: 1508-9.

32. Cestari TF, Martignago BF. Scabies, pediculosis, bedbugs, and stinkbugs: uncommon presentations. Clin Dermatol 2005; 23: 545-54.

33. Zhu YI, Stiller MJ. Arthropods and skin diseases. Int J Dermatol 2002; 41: 533-49.

34. Fletcher CL, Ardern-Jones MR, Hay RJ. Widespread bullous eruption due to multiple bed bug bites. Clin Exp Dermatol 2002; 27: 74-5.

35. Kinnear J. Epidemic of bullous erythema on legs due to bedbugs. Lancet 1948; 2: 55.

36. Masetti M, Bruschi F. Bedbug infestations recorded in Central Italy. Parasitol Int 2007; 56: 81-3.

37. Abdel-Naser MB, Lotfy RA, Al-Sherbiny MM, et al. Patients with papular urticaria have IgG antibodies to bedbug (Cimex lectularius) antigens. Parasitol Res 2006; 98: 550-6.

38. Liebold K, Schliemann-Willers S, Wollina U. Disseminated bullous eruption with systemic reaction caused by Cimex lectularius. J Eur Acad Dermatol Venereol 2003; 17: 461-3.

39. Sansom JE, Reynolds NJ, Peachey RD. Delayed reaction to bed bug bites. Arch Dermatol 1992; 128: 272-3.

40. Ukleja-Sokolowska N, Sokolowski L, Gawronska-Ukleja E, et al. Application of native prick test in diagnosis of bed bug allergy. Adv Dermatol Allergol 2013; 30: 62-4.

41. Bennett GW, Gondhalekar AD, Wang C, et al. Using research and education to implement practical bed bug control programs in multifamily housing. Pest Manag Sci 2016; 72: 8-14.

42. Woloski JR, Burman D, Adebona O. Mite and bed bug infections. Prim Care 2018; 45: 409-21.

43. McNeill C, Jarrett A, Shreve MD. Bed bugs: current treatment guidelines. J Nurse Practitioners 2017; 13: 381-8. 
44. Foundation BB. Bedbug Management Version 2 European Code of Practice 2013: 33.

45. Bed Bugs - Importance, Biology, and Control Strategies. Armed Forces Pest Management Board 2019; Technical Guide No. 44.

46. Burrows S, Perron S, Susser S. Suicide following an infestation of bed bugs. Am J Case Rep 2013; 14: 176-8.

47. Susser SR, Perron S, Fournier M, et al. Mental health effects from urban bed bug infestation (Cimex lectularius L.): a cross-sectional study. BMJ Open 2012; 2: e000838.

48. Ashcroft R, Seko Y, Chan LF, et al. The mental health impact of bed bug infestations: a scoping review. Int J Public Health 2015; 60: 827-37.

49. Bircher AJ. Systemic immediate allergic reactions to arthropod stings and bites. Dermatology 2005; 210: 119-27.

50. Rahmani F, Banan Khojasteh SM, Bakhtavar HE, et al. Poisonous spiders: bites, symptoms, and treatment; an educational review. Emerg (Tehran) 2014; 2: 54-8.

51. Juckett G. Arthropod bites. Am Fam Physician 2013; 88: 841-7.

52. Turgeon EW. Insects and spiders: infestations and bites. Can Fam Physician 1987; 33: 2369-73.

53. Salavastru CM, Chosidow O, Boffa MJ, et al. European guideline for the management of scabies. J Eur Acad Dermatol Venereol 2017; 31: 1248-53.

54. Krasagakis K, Samonis G, Valachis A, et al. Local complications of erysipelas: a study of associated risk factors. Clin Exp Dermatol 2011; 36: 351-4.

55. Heller MM, Wong JW, Lee ES, et al. Delusional infestations: clinical presentation, diagnosis and treatment. Int J Dermatol 2013; 52: 775-83.

56. Wareham DW, Breuer J. Herpes zoster. BMJ 2007; 334: 1211-5.

57. Arora S, Malik A, Balki A. Reactive perforating collagenosis. Indian Dermatol Online J 2016; 7: 139-40.

58. Usatine RP, Riojas M. Diagnosis and management of contact dermatitis. Am Fam Physician 2010; 82: 249-55.

59. Karpati S. Dermatitis herpetiformis. Clin Dermatol 2012; 30: 56-9.

60. Sokumbi O, Wetter DA. Clinical features, diagnosis, and treatment of erythema multiforme: a review for the practicing dermatologist. Int J Dermatol 2012; 51: 889-902.

61. Guide SV, Marinkovich MP. Linear IgA bullous dermatosis. Clin Dermatol 2001; 19: 719-27.

62. Medvecz M, Kiss N, Harsing J, et al. Lymphomatoid papulosis type B in a patient with crohn's disease treated with TNFalpha inhibitors infliximab and adalimumab. Acta Dermatovenerol Croat 2019; 27: 202-4.

63. Elpern DJ, Morison WL, Hood AF. Papulovesicular light eruption. A defined subset of polymorphous light eruption. Arch Dermatol 1985; 121: 1286-8.

64. Ilkit M, Durdu M, Karakas M. Cutaneous id reactions: a comprehensive review of clinical manifestations, epidemiology, etiology, and management. Crit Rev Microbiol 2012; 38: 191202.

65. Khachemoune A, Blyumin M L. Pityriasis lichenoides: pathophysiology, classification, and treatment. Am J Clin Dermatol 2007; 8: 29-36.

66. Fernandes NF, Rozdeba PJ, Schwartz RA, et al. Pityriasis lichenoides et varioliformis acuta: a disease spectrum. Int J Dermatol 2010; 49: 257-61.

67. Lee MR, Shumack S. Prurigo nodularis: a review. Australas J Dermatol 2005; 46: 211-8.

68. Matz H, Orion E, Wolf R. Pruritic urticarial papules and plaques of pregnancy: polymorphic eruption of pregnancy (PUPPP). Clin Dermatol 2006; 24: 105-8.
69. Nofal A, Abdelmaksoud A, Amer H, et al. Sweet's syndrome: diagnostic criteria revisited. J Dtsch Dermatol Ges 2017; 15: 1081-8.

70. Ahmed AM, Pritchard S, Reichenberg J. A review of cutaneous drug eruptions. Clin Geriatr Med 2013; 29: 527-45.

71. Deacock SJ. An approach to the patient with urticaria. Clin Exp Immunol 2008; 153: 151-61. 